\title{
ECONOMICS
}

\section{HOW AUSTRALIAN FARMERS DEAL WITH RISK}

\author{
by
}

Amy Khuu

and

Ernst Juerg Weber

Business School

University of Western Australia

DISCUSSION PAPER 12.07 


\title{
HOW AUSTRALIAN FARMERS DEAL WITH RISK
}

\author{
Amy Khuu \\ and \\ Ernst Juerg Weber \\ Business School \\ University of Western Australia \\ Crawley WA 6009
}

May 2012

\section{DISCUSSION PAPER 12.07}

This paper is based on the research that Amy Khuu conducted for her Honours thesis at the University of Western Australia in 2011. Helpful comments by Ken Clements and the participants in a seminar as well as the financial support by the UWA Business School are gratefully acknowledged.Email: khuua03@student.uwa.edu.au; juerg.weber@uwa.edu.au. 


\begin{abstract}
Farm survey data show that the risk aversion of West Australian farmers is comparable to that of other asset holders. An increase in the variability of crop yield by $20 \%$, which may be caused by future climate change, would raise their willingness to pay for crop insurance almost one-to-one by 19\%. West Australian farmers can insure against hail, fire and some other perils but not against the greatest risk - drought. The farm survey indicates that adverse selection does not arise in the existing market for crop insurance because insurance premiums reflect the risk of crop failure. However, a future supplier of drought insurance must take into consideration that drought insurance might give rise to moral hazard, changing the risk management practices of farmers.
\end{abstract}




\section{Introduction}

There are two main categories of risk associated with growing crops: uncertainty associated with the amount or quality of output generated (yield or production risk) and uncertainty about the price received for output (price risk). This paper is concerned with the production risks associated with dryland broadacre cropping, which relies on rainfall for production. Crop production may be adversely affected by weather conditions - drought, flooding, hail, heavy winds and frost - and by fire, plant disease and pests. The largest cause of uncertainty is variation in rainfall, which is highly variable in Australia. Separate from discrete seasonal variation in rainfall are droughts, which may be defined in an agricultural context as 'a protracted period of deficient precipitation resulting in extensive damage to crops, resulting in loss of yield' (Lindesay 2003, p. 31).

Data from a survey of Western Australian farmers is used to consider two issues in farm risk management. First, the farmers' willingness to pay for insurance that protects against wheat yield variability is modelled as a function of risk aversion, risk of crop failure and government assistance. Second, production data is used to test whether farmers are able to make use of seasonal weather forecasts to tailor their planting strategy and thus manage the risk of crop failure caused by low rainfall. The empirical findings shed light on the prevalence of adverse selection and moral hazard in the market for crop insurance. Section 2 provides a brief introduction to agricultural risk management in Australia. Section 3 sets out the theory of risk aversion, adverse selection and moral hazard, which explains the structure of the market for crop insurance in Western Australia. Section 4 outlines details of the farm survey that was conducted and Section 5 contains the empirical models and estimation results. 


\section{Agricultural Risk Management in Western Australia}

Market based tools for the transfer of production risks are limited in Australian agriculture. Broadacre crops may be insured against hail and fire damage but not against losses of crop yield caused by lack of rain (drought), flood or frost. Most insurance policies combine coverage for losses caused by hail and fire and a number of other perils including damage caused by lightning or spontaneous combustion, explosion, chemical overspray from neighbouring properties and straying livestock. There is no multi-peril crop insurance (MPCI) available that would also cover damages caused by drought, flood and frost. In fact, these risks to crops are uninsurable in Australia. The empirical analysis in this paper is based on the available hail insurance broadly defined to cover hail and all other perils included in a crop hail policy.

Premiums for broadacre hail insurance are based upon the location of the farm and the type of crop being covered. Location ratings relate to weather patterns and are calculated on a shire or postcode basis - shires that have greater prevalence of hail attract higher premiums. Similarly, insurers charge more for crops that are more prone to hail damage. In Australia farm yield history is not taken into account when premiums are set. Premiums generally range from $0.5 \%-2.5 \%$ of the insured crop value with the majority of premiums being under $1 \%$ (Multi Peril Crop Insurance Task Force 2003, p. 21).

In Australia agricultural insurance is provided by three private insurers that underwrite crop and livestock policies, nine that offer crop insurance only and three that offer livestock policies only (Mahul \& Stutley 2010, p. 11). Yearly premium totals for agricultural insurance are volatile and influenced by seasonal weather, which affects the volume of insured crops, and commodity prices, which affect their value. A World Bank survey estimated that in 2007, $50 \%$ of Australian farmers had a crop insurance policy and $50 \%$ of the cropped area was 
insured (Mahul \& Stutley 2010, p. 12). Premiums for broadacre crops were estimated to be \$US 96 million in 2008. Total premiums for all types of crops are approximately \$A 200 million, representing about \$A 7 - \$A 10 billion worth of crops insured (Kimura \& Antón 2011, p. 23). Private sector reinsurance is well developed in Australia with about $85 \%$ of exposure being reinsured.

The Australian Federal Government provides limited support to farmers for drought. Under the National Drought Policy (NDP), farmers receive short term financial assistance if they are affected by droughts that are 'beyond the scope of normal risk management' (Botterill 2003, p. 71). Less severe droughts are considered by the Government to be an inherent risk of the Australian farming environment that should be left to farmers to manage themselves. Three main programs are available to farmers situated in areas declared as experiencing an ‘Exceptional Circumstance’: EC Relief Payment (ECRP), commonly called 'income support', provides payments for basic living expenses; EC Interest Rate Subsidy (ECIRS) provides subsidies on interest payable on loans; and EC Exit Package is designed to assist farmers in financial difficulty to leave the industry and re-establish themselves outside of farming. In 2007-08, 23\% of farms received financial support at a cost of \$380 million for ECRP, \$604 million for ECIRS and \$10 million for the EC Exit Package (Productivity Commission 2009, p. xxii). The current policy climate appears to be moving away from providing ex-post financial support and towards helping farmers develop a self-managed risk mitigation approach (Primary Industries Ministerial Council 2011). 


\section{Risk Aversion, Adverse Selection and Moral Hazard}

A crucial determinant of the demand for insurance is risk aversion. A risk averse individual values a risky prospect at less than its expected value and is thus willing to pay for insurance that grants certainty of income. Risk aversion is a property of the utility function that can be measured by calculating the income elasticity of marginal utility:

$$
R(Y)=-\frac{d U^{\prime}(Y)}{d Y} \frac{Y}{U^{\prime}(Y)}=-\frac{Y U^{\prime \prime}(Y)}{U^{\prime}(Y)}
$$

The measure $R$, which is also known as the coefficient of relative risk aversion, is calculated at a specific level of income $Y$ and, as elasticity, is dimensionless. A positive value of $R$ indicates risk aversion; the higher the value, the more concave the utility function and the stronger the risk aversion. A value of $R=0$ indicates that the utility function is linear and the individual is risk neutral.

In the context of insurance, the risk premium $\rho$ is the amount of income that an individual is willing to give up in order to be indifferent between the certain level of income given by insurance and the expected income that would be earned without insurance. The risk premium depends positively on risk (the objective component) and risk aversion (the subjective component). Newbery and Stiglitz (1981, p. 73) show that the risk premium can be related to the coefficient of relative risk aversion by carrying out Taylor expansions of $U(Y)$ at the risky income $\tilde{Y}$ and at the certainty equivalent level of income $\hat{Y}$, which is the mean income $\bar{Y}$ minus the risk premium $\rho$. The relative risk premium as a fraction of mean income can be expressed as a function of risk aversion and risk in the following manner:

$$
\frac{\rho}{\bar{Y}} \approx-\frac{1}{2} \frac{\delta^{2}}{\bar{Y}^{2}} \frac{\bar{Y} U^{\prime \prime}(\bar{Y})}{U^{\prime}(\bar{Y})}=\frac{1}{2} R \sigma_{Y}^{2}
$$


In the preceding equation, $\delta$ is the standard deviation in income and $\sigma_{Y}$ is the coefficient of variation of income, $\sigma_{Y}=\delta / \bar{Y}$. Thus, the relative risk premium is approximately half the squared coefficient of variation multiplied by the coefficient of relative risk aversion $R$. Expressing the risk premium this way is useful because it is dimensionless and can be compared across agents with different mean incomes. The relative risk premium increases with the squared coefficient of variation (greater risk) and with the coefficient of relative risk aversion (greater risk aversion). In Section 5 the relative risk premium is estimated using farm survey data in Western Australia.

Insurance markets differ from traditional goods markets because the distinction between demand and supply breaks down. Adverse selection implies that the cost of providing insurance is directly related to the demand for insurance. Holding other factors constant, buyers with a higher probability of loss will expect a greater return from an insurance policy than low risk buyers and, consequently, will have greater willingness to pay for the policy. Adverse selection arises due to asymmetry of information between buyers and insurance providers. Insurers that do not possess information about differences in buyer risk will offer an average premium rate to a heterogeneous risk pool with high risk buyers tending to purchase greater coverage and low risk buyers being priced out (Rothschild and Stiglitz 1976). Adverse selection may cause underinsurance or complete market failure as low risk individuals exit the market. In a crop insurance market, adverse selection can arise if farmers know more about their chance of crop failure and expected yield than insurers, who may have access to regional yield data but may lack farm level data.

Moral hazard is the change in unobservable behaviour induced by the existence of an insurance contract. It occurs because insurance shifts the risk of loss from the insured to the insurer. Zweifel \& Breyer (1997, p. 157) distinguish between ex-post and ex-ante moral 
hazard. If the size of the loss increases as a result of the contract, the moral hazard is referred to as ex-post. This may be because the policy holder no longer exerts as much effort into taking measures that reduce the severity of a loss when it occurs. If the probability of a loss is increased due to changed behaviour towards the risk, the moral hazard is referred to as exante as it occurs before the loss.

In this paper it is theorised that farmers can avoid losses by planting less in low-rainfall seasons, such as predicted El Nino years. Surveys by the Australian Bureau of Agriculture and Resource Economics (ABARE); the Department of Agriculture, Fisheries and Forestry; and the Bureau of Meteorology found significant knowledge of and use of seasonal weather forecasts in agricultural management decisions (Hayman et al. 2007, p. 977). If farmers can reliably predict the weather for a plant cycle, a positive correlation between area planted and crop yield in t/ha would be expected. Multi-peril crop insurance shifts the risk of crop failure from the farmer to the insurance company, reducing the incentive to behave prudently. As a consequence, less attention will be paid to weather forecasts and the crop area will remain large in years with poor weather conditions. This gives rise to ex-post moral hazard because crop insurance does not increase the probability of a loss but it raises the size of a loss associated with a bigger crop. Moral hazard promotes inefficient farming and will eventually cause premiums to rise as insurance companies have higher expected costs over the longer time frame.

\section{Survey Outline}

The farm survey was conducted with the cooperation of broadacre farmers belonging to Western Australian grower groups. Surveys were distributed via email to 27 grower groups during June-September 2011. As well as this, hard copies of the questionnaire were handed 
out at committee meetings of the North Kojonup Production Group and the Liebe Group in Dalwallinu. Respondents were given the opportunity to answer using email, surface mail, fax or an online survey hosting website. A total of 19 usable responses from ten different postcodes were obtained. The Appendix shows the grower groups that were approached, the shire locations of the respondents and the questionnaire sent out to farmers.

The survey was entitled ‘Agricultural Risk Management in Western Australia’ and covered a range of issues on the relevant subject. Growers were asked questions arranged into five sections: farm background, hedging arrangements for price risk, arrangements for hail crop insurance, uninsurable risks, and other risk management tools. Each section included open ended questions that allowed farmers to comment on their exposure to risk and their attitude towards insurance. When asked 'what are the major risks affecting your farm's production and income?' the most common answers were lack of or unpredictability in rainfall, frost, exchange rate and grain price volatility, and increasing input costs. Responses to the question '[what] measures do you take to prevent uninsurable losses such as drought, frost or flood?' included staggered seeding times, planting less crop in predicted low rainfall seasons, diversifying crop types and other best management practices.

In order to obtain a measure of production variability, farmers were asked to give details of their crop production from 2006-2010 in terms of yield in t/ha and hectares planted. ${ }^{1}$ The mean area planted over five years was 15,632 ha, while the median was 10,813 ha. The average yield of all crops produced over the five years (total tonnes produced/total hectares planted) had a mean of $1.50 \mathrm{t} / \mathrm{ha}$, median of $1.44 \mathrm{t} / \mathrm{ha}$ and standard deviation of $0.26 \mathrm{t} / \mathrm{ha}$. The minimum was $1.13 \mathrm{t} / \mathrm{ha}$ and the maximum $2.03 \mathrm{t} / \mathrm{ha}$. Of the $420,880 \mathrm{t}$ produced by the 19 farms in five years, wheat accounted for 354,522 t; consequently, the following analysis will focus on total crop and wheat production.

\footnotetext{
${ }^{1}$ The survey data are included in a technical Appendix that is available on request.
} 
Wheat production in terms of both hectares planted and tonnes per hectare varied strongly over the five years. 2008 and 2009 were high-producing years with 118,649 t and 103,472 t respectively, while 2006 and 2007 had less than 42,000 t. In general, there were more hectares planted in the higher yielding years, which suggests that farmers took advantage of seasonal weather forecasts. The standard deviation in the total wheat yield of all farms combined over the five years was $0.56 \mathrm{t} / \mathrm{ha}$. In comparison, the mean standard deviation of wheat yield on individual farms over the five years was $0.71 \mathrm{t} / \mathrm{ha}$. Controlling for geographical location, the mean standard deviation of wheat yield between years for the six farms located in Dalwallinu was $0.68 \mathrm{t} / \mathrm{ha}$. The fact that there is greater variability in yield within farms than across farms means that an insurance company setting premiums based on shire yield data for a product that insures against yield loss will set them too low. Farmers who have more variable yields have a greater probability of their yield falling below the insured level and should be charged higher premiums. Charging a premium based on shire level variability will underestimate the probability of loss.

The most noticeable feature from farmers' responses regarding their hail insurance is that although premiums vary, almost all farmers take out full coverage. In terms of percentage of expected crop value, the mean coverage chosen was $87 \%$ with 14 out of 19 farmers choosing to cover their entire crop. Three farmers chose between $80 \%$ and $95 \%$ coverage and two had no insurance policy. The lowest premium paid was $0.49 \%$ of the insured crop value while the highest was $2 \%$. The mean premium was $0.75 \%$ with a standard deviation of $0.43 \%$. Removing the two farms that did not buy insurance, the mean premium charged was $0.84 \%$. The variation in premiums is to be expected due to the variation in farm locations and types of crop planted, as hail premiums are primarily based on these two factors. The high take up of insurance suggests that adverse selection does not impair the market for hail insurance. There is no asymmetric information because it is unlikely that a farmer has a better predictive ability 
over the risk of hail damage than an insurance company that has access to the same meteorological information as the farmer.

\section{Empirical Results}

In this section farmers' willingness to pay for insurance that protects against wheat yield variability is modelled. Hail insurance has the effect of guaranteeing a certain yield in $\mathrm{t} / \mathrm{ha}$ for the farmer's crop in the event of damage. This is similar to drought insurance or multi-peril crop insurance, which are not available in Australia. The model estimates the coefficient of relative risk aversion and the impact that the Federal Government's ECIRS program has on willingness to pay for hail insurance.

The empirical model is based on equation 2 with an extra term being added that captures the effect of government assistance in the event of crop failure.

$$
\begin{aligned}
& \frac{\rho_{h}}{\bar{Y}}=\beta_{0}+\beta_{1} \text { ECIRS }+\frac{1}{2} R \sigma_{Y}^{2}+u \\
& \frac{\rho_{h}}{\bar{Y}}=\beta_{0}+\beta_{1} \text { ECIRS }+\beta_{2} \sigma_{Y}^{2}+u
\end{aligned}
$$

The dependent variable $\rho_{h} / \bar{Y}$ is the hail insurance premium as a percentage of mean crop value. Risk is measured as the squared coefficient of variation of wheat yield in $\mathrm{t} / \mathrm{ha}, \sigma_{Y}^{2}$. The estimated value of the slope parameter $\beta_{2}$ gives an estimate of the coefficient of relative risk aversion $R$, using $R=2 \beta_{2}$. The risk premium is the amount of income that, when given in exchange for insurance, will equalise utility in the loss and non-loss states. Farmers actually pay an 'unfair' premium that includes an extra loading factor that is determined by the insurance company's administration costs and profit. The intercept term $\beta_{0}$ may be interpreted 
as the loading factor that farmers pay to the insurance company independent of risk. ECIRS is a dummy variable that is set equal to 1 if the farm has ever received emergency aid in the form of an Exceptional Circumstances Interest Rate Subsidy. This variable is used to test whether access to government support reduces the willingness to pay for insurance. $u$ is the error term.

Equation 5 was estimated using OLS, corrected for heteroscedasticity. The full regression output is included in the technical Appendix.

$$
\begin{aligned}
& \frac{\rho_{h}}{\bar{Y}}=0.39-0.22 \text { ECIRS }+1.3 \sigma_{Y}^{2} \\
& \begin{array}{lll}
(0.14) \quad(0.12) & (0.47)
\end{array} \\
& R^{2}=0.25, \mathrm{df}=15
\end{aligned}
$$

The regression results indicate that the farmers’ willingness to pay for hail insurance strongly depends on the variability of crop yield. The estimated parameter $\beta_{2}$ equals 1.3 with a standard error of 0.47 . The mean value of the coefficient of variation $\sigma_{Y}$ is 0.48 in the regression sample. An increase by $20 \%$, which might be caused by future climate change, would raise the squared coefficient of variation from 0.23 to 0.33 , adding 0.13 percentage points to the relative insurance premium. Since the mean premium is $0.69 \%$, this amounts to an increase in the relative insurance premium of $19 \%$. The estimated value for $\beta_{2}$ implies that the coefficient of relative risk aversion $R$ is 2.6, suggesting that farmers are moderately strongly risk averse. When modelling aggregate consumption and saving, macroeconomists work with a coefficient of relative risk aversion between 1 and 2. Financial economists, who focus on the behaviour of individual investors, typically find somewhat larger coefficients of 
relative risk aversion, between 2 and 4 and sometimes even higher. This study is in line with those of financial economists because it focuses on individual asset holders - here farmers. ${ }^{2}$

The estimated value of $\beta_{1}$ is -0.22 with a standard error of 0.12 . The negative value implies that receiving ECIRS payments from the government reduces willingness to pay for insurance. This finding is consistent with the view of the Productivity Commission (2009) that ECIRS payments create a perverse incentive for producers to be less self-reliant and manage the risk of drought less effectively in the knowledge that they will receive government support. The ECIRS program is effectively a substitute for holding drought insurance and as a result reduces willingness to pay for insurance. The policy is one of the contributing factors for the failure of a private drought insurance market to develop in Australia. Removing the ECIRS variable from the model yields an $R$ of 2.1. ${ }^{3}$

The positive value of $R$ indicates that farmers are risk averse. With risk aversion, the willingness to pay for yield insurance depends positively on the variation in crop yield; that is, higher risk farmers are willing to pay more for insurance. This may give rise to adverse selection in markets for insurance that protect against losses in yield caused by hail or other events. Farmers who have greater variation in their wheat yield are more likely to suffer crop failures and are more likely to claim. They are associated with higher expected costs to cover and should be charged higher premiums. In Western Australia insurance companies collect average yield data for entire shires. Nevertheless, adverse selection does not appear to be a major problem in the market for hail insurance because the estimated equation 5 indicates that insurance companies are able to charge premiums that reflect the objective risk of the insured farmers.

\footnotetext{
${ }^{2}$ Warren (2007) provides a meta-analysis of the coefficient of relative risk aversion. Bond and Wonder (1980) found that Australian farmers are only moderately risk averse.

${ }^{3}$ In demand analysis the inverse of $R$ is called the income flexibility. Gao (2012) and Clements (2008) show that the income flexibility is close to 0.5 .
} 
The potential for moral hazard can be gauged by considering the effort of farmers to avoid crop losses. One risk management strategy involves the use of seasonal weather forecasts to determine the optimal crop area to be planted. Insurance may give rise to ex-post moral hazard because it reduces the incentive to pay attention to seasonal weather forecasts, increasing the size of the loss should adverse weather conditions arise during the planting cycle. A positive correlation between hectares planted and crop yield in $\mathrm{t} / \mathrm{ha}$ indicates that forward looking farmers take advantage of seasonal weather forecasts.

For the empirical analysis a panel data set was compiled using the five years of production data collected from each farm. A fixed effects panel regression removes time invariant data, allowing assessment of the predictor's net effect (in this case the effect of yield in t/ha on hectares planted). It should be noted that while it is theorised that a farmer's decision to plant is based on the season's predicted or expected yield, the data regressed on is the actual t/ha produced. The fixed effects panel regression model is:

$$
{\text { Crop } \text { Area }_{i t}=\text { a Crop Yield }}_{i t}+u_{i t}
$$

The crop area is measured in hectares and crop yield is tonnes per hectare. $u_{i t}$ is the error term. There is no intercept term as it is wiped out as a time invariant variable. The estimated model for wheat is:

$$
\begin{aligned}
{\text { Crop } \text { Area }_{i t}=} & \underset{(152.13)}{ }\left(34.26 \text { Crop Yield }_{i t}\right. \\
R^{2}=0.96, \mathrm{df}= & 75
\end{aligned}
$$

The estimated parameter $a$ is 434.26 with a standard error of 152.13 . Thus, it can be concluded that a significant positive relationship exists between the area planted and wheat yield. The regression was also run for the composite value of all crops as well as barley with similar results. These findings show that farmers plant more crops in higher yielding years, 
suggesting that they are able to predict weather conditions by using meteorological information and to manage the risk appropriately. There exists the potential for moral hazard as the introduction of drought insurance would reduce the incentive to behave prudently.

\section{Conclusion}

The findings in this paper shed light on the provision of crop yield insurance in Western Australia. First, there is a demand for insurance as the degree of risk aversion of Western Australian farmers is similar to that of other asset holders. Second, adverse selection plays a minor role in the market for hail insurance because observed insurance premiums reflect farm specific risks. Third, government emergency assistance reduces the willingness to pay for insurance. Fourth, there arises the potential for moral hazard because with no drought insurance farmers manage the risk of crop failure by using meteorological information. A future supplier of drought insurance must take into consideration that the introduction of drought insurance will change the risk management practices of farmers.

It remains an open question to what degree the findings on hail insurance carry over to multiperil crop insurance that also covers drought and frost. In analysing the stability of risk preferences across five different types of insurance, Einav et al. (2012) found that an individual's choice in one insurance market has substantial predictive power for their choices in other insurance markets. Insurance domains that are 'similar' such as prescription drug insurance and health insurance are particularly good predictors of each other. It is reasonable to assume that the same applies for hail insurance and drought insurance because the loss caused by damage from hail and drought is the same - they both affect farm income by way of damaging crops. However, there is no reason to believe that insurance companies have access to the same information even in similar markets. In particular, it seems that there exists 
less private information that is hidden from insurance companies in the market for hail insurance than the market for drought insurance. The hail risk is a given quantity that is based on historical observations whereas the drought risk changes from one planting season to the next in a predictable manner. Insurance companies do not know how skilfully farmers use seasonal weather forecasts and meteorological information, if at all. For this reason, drought insurance is more prone to asymmetric information than hail insurance, which may explain the failure of the market for drought insurance in Australia. 


\section{References}

Bond, GE \& Wonder, B 1980, 'Risk attitudes among Australian farmers', Australian Journal of Agricultural Economics, vol. 24, pp. 16-34.

Botterill, LC 2003, 'Uncertain climate: the recent history of drought policy in Australia', Australian Journal of Politics and History, vol. 49, no. 1, pp. 61-74.

Clements, KW 2008, 'Price elasticities of demand are minus one-half', Economics Letters, vol. 99/3, pp. 490-493.

Einav, L, Finkelstein, A, Pascu, I \& Cullen, MR 2012, 'How general are risk preferences? Choices under uncertainty in different domains', American Economic Review, forthcoming.

Gao, X 2012, 'A comprehensive approach to functional form in demand analysis', in The economic behaviour of seven billion consumers: Food, functional form and quality, Chapter 3, PhD dissertation, Economics, University of Western Australia.

Hayman, P, Crean, J, Mullen, J \& Parton K 2007, 'How do probabilistic seasonal climate forecasts compare with other innovations that Australian farmers are encouraged to adopt?’, Australian Journal of Agricultural Research, vol. 58, pp. 975-984.

Kimura, S \& Antón, J 2011, 'Risk management in agriculture in Australia', OECD Food, Agriculture and Fisheries Working Papers, No. 39, OECD Publishing.

Lindesay, JA 2003, 'Climate and drought in Australia', in Beyond drought: people, policy and perspectives, eds L Botterill \& M Fisher, CSIRO Publishing, Melbourne.

Mahul, O \& Stutley, CJ 2010, International experiences with agricultural insurance: findings from a World Bank survey of 65 countries, World Bank, Washington.

Multi Peril Crop Insurance Taskforce 2003, Report to the Minister for Agriculture, Forestry and Fisheries, Department of Agriculture, Fisheries and Forestry, Canberra.

Newbery, DMG \& Stiglitz JE 1981, The theory of commodity price stabilization, Oxford University Press, New York.

Primary Industries Ministerial Council 2011, Communiqué, 15 April, Primary Industries Ministerial Council, Canberra.

Productivity Commission 2009, Government Drought Support, Report No. 46, Productivity Commission, Melbourne.

Rothschild, M \& Stiglitz, J 1976, 'Equilibrium in competitive insurance markets: an essay on the economics of imperfect information', The Quarterly Journal of Economics, vol. 90, no. 4, pp. 629-649. 
Warren, M 2007, Estimation of the coefficient of relative risk aversion: A meta-analysis, Honours dissertation, Economics, University of Western Australia.

Zweifel, P \& Breyer, F 1997, Health economics, Oxford University Press, New York. 


\section{Appendix}

Table 1. Grower Groups

\begin{tabular}{|l|l|}
\hline Region & Group Name \\
\hline Northern Agricultural Region & Liebe Group \\
& Mingenew-Irwin Group \\
& Morawa Farm Improvement Group \\
& North East Farming Futures \\
& Northern Agri Group \\
& West Midlands Group \\
& Yuna Farm Improvement Group \\
\hline Avon Region & Bodallin Catchment Group \\
& Corrigin Farm Improvement Group \\
& Duli Farm Improvement Group \\
& Evergreen Farming \\
& Facey Group \\
& Greenhills Production Group \\
& Holtrock Group \\
\hline South West Region & Bugs and Biology \\
& North Kojonup Production Group \\
& Nyabing Farm Improvement Group \\
& Southern DIRT \\
& Tambellup/Broomehill Farmers \\
& West Wagin Top Crop Group \\
\hline \multirow{5}{*}{ South Coast Region } & Esperance Regional Forum \\
& Fitzgerald Biosphere Group \\
& Gillamii Centre \\
& Jerdacuttup Top Crop and Pasture Group \\
& Munglinup Local Farmer Group \\
& North Mallee Farm Improvement Group \\
& South East Premium Wheat Growers Association \\
\hline
\end{tabular}


Table 2. Farm Location and Size

\begin{tabular}{|c|c|c|c|c|}
\hline \multirow[b]{2}{*}{ Farm \# } & \multirow[b]{2}{*}{ Shire } & \multirow{2}{*}{$\begin{array}{l}\text { Post } \\
\text { Code }\end{array}$} & Farm Area & Crop Area \\
\hline & & & hectares & hectares \\
\hline 1 & Dalwallinu & 6609 & 6,260 & 5,200 \\
\hline 2 & Corrigin & 6375 & 3,332 & 1,300 \\
\hline 3 & Kojonup & 6395 & 1,300 & 300 \\
\hline 4 & Morawa & 6623 & 4,250 & 4,250 \\
\hline 5 & Morawa & 6623 & 1,950 & 1,634 \\
\hline 6 & Mullewa & 6630 & 10,000 & 10,000 \\
\hline 7 & Morawa & 6623 & 6,680 & 5,050 \\
\hline 8 & Bruce Rock & 6418 & 2,240 & 1,100 \\
\hline 9 & Wickepin / Kirk Rock & 6372 & 6,500 & 4,470 \\
\hline 10 & Dalwallinu & 6609 & 5,100 & 4,000 \\
\hline 11 & Dalwallinu & 6612 & 10,200 & 8,500 \\
\hline 12 & Dalwallinu & 6612 & 8,000 & 6,000 \\
\hline 13 & Dalwallinu & 6612 & 4,800 & 3,400 \\
\hline 14 & Kojonup & 6395 & 1,150 & 470 \\
\hline 15 & Kojonup & 6395 & 1,100 & 250 \\
\hline 16 & Wickepin / Dumbleyung & 6361 & 4,139 & 2,141 \\
\hline 17 & Wickepin & 6370 & 2,200 & 1,000 \\
\hline 18 & Dalwallinu & 6609 & 33,400 & 27,600 \\
\hline 19 & Corrigin & 6375 & 2,300 & 900 \\
\hline
\end{tabular}




\section{Farm Survey \\ Agricultural Risk Management in Western Australia}

\section{Contact}

Amy Khuu, Department of Economics, University of Western Australia, Email: khuua03@student.uwa.edu.au (Please email completed questions to this address.)

\section{Privacy Policy}

The information collected will be treated as strictly confidential and will not be used for any other purpose apart from research conducted by the principal investigator Amy Khuu. In your answers do not include any information that would identify you personally or your farm.

\section{Supervisor}

Associate Professor E. Juerg Weber, Department of Economics, University of Western Australia, Email: juerg.weber@uwa.edu.au

\section{Questions}

Please answer all questions, partial answers will also be helpful.

\section{Farm background}

a) Where is your farm located?

Shire/District:

Post code:

b) What is the area of your farm?

In total (hectares):

Area of land devoted to crops (hectares):

c) Please record the crops that you have grown for the past five years. What has been the yield of each crop for each year?

\begin{tabular}{|l|l|l|l|}
\hline Year & \multicolumn{1}{|c|}{ Crops } & Area (ha) & Yield (t) \\
\hline 2010 & Wheat & & \\
\hline & Barley & & \\
\hline & Canola & & \\
\hline & Lupins & & \\
\hline 2009 & Other: ............. & & \\
& Wheat & & \\
\cline { 2 - 4 } & Barley & & \\
\hline & Canola & & \\
\hline & Lupins & & \\
\hline & Other: ............. & & \\
\hline
\end{tabular}




\begin{tabular}{|c|l|l|l|}
\hline 2008 & Wheat & & \\
\hline & Barley & & \\
\hline & Canola & & \\
\hline & Lupins & & \\
\hline & Other: .............. & & \\
\hline 2007 & Wheat & & \\
\hline & Barley & & \\
\hline & Canola & & \\
\hline & Lupins & & \\
\hline & Other: ............. & & \\
\hline & Wheat & & \\
\hline & Barley & & \\
\hline & Canola & & \\
\hline
\end{tabular}

d) What are the major risks affecting your farm's production and income? Please give details:

\section{Hedging arrangements for price risk}

a) What percentage of your crops do you usually hedge?

Wheat

Barley

Canola

Lupins

Other:

Average for total crop: 
b) Percentage of crop sold using the following methods? (average)

Forward contracts:

Futures contracts:

Commodity swaps:

Basis Contracts:

Options:

Grain pools:

Other:

c) What hedging instruments do you use for each crop type? Give company and product name if possible.

Wheat

Barley

Canola

Lupins

Other

\section{Insurance arrangements (normal yield type insurance, i.e. hail, fire, etc.)}

a) Do you currently have a crop insurance policy?

Yes/No:

If no, why not? (please explain)

- Too expensive:

- Not necessary:

- Other:

If yes, how much do you pay each year for crop insurance (average)?

In \$ terms:

As a percentage of expected crop value:

b) What amount are you insured for?

In \$ terms:

As a percentage of expected crop value:

c) What is the highest premium as a percentage of expected crop value that you would be willing to pay for your existing crop insurance? 
d) Please give details of any insurance claims you have made in the past ten years:

\begin{tabular}{|c|c|c|}
\hline Year & Reason for claim & Amount \\
\hline & & \\
\hline & & \\
\hline & & \\
\hline & & \\
\hline & & \\
\hline & & \\
\hline
\end{tabular}

e) Please give details of any crop failures that you did not claim for, or where unable to claim for in the past ten years:

\begin{tabular}{|l|l|l|}
\hline Year & Reason for failure & $\begin{array}{l}\text { Size of loss, i.e. total crop failure or } \\
\text { percentage reduction in yield. }\end{array}$ \\
\hline & & \\
& & \\
& & \\
\hline
\end{tabular}

\section{Uninsurable Risks}

This question deals with potential crop insurance for drought, frost and flood which currently does not exist in Australia or is hard to get.

1. Would you be interested in insurance that protects against losses in production due to drought, frost or flood?

Yes/No:

If no, why not?

- Availability of assistance from the government is sufficient:

- Other - please give reason:

If yes, how much would you be willing to pay for such insurance (as a percentage of expected crop value)?

2. Are you taking other measures to prevent uninsurable losses caused by drought, frost and flood? Please give details: 


\section{Other risk management tools}

a) Government Support

Have you ever received government support as a result of your farm being declared as experiencing an 'Exceptional Circumstance' (EC)? Please give details:

- $\quad$ Exceptional Circumstances Relief Payments (ECRP) - commonly called 'Income Support'

Years received:

Amount received:

- $\quad$ Exceptional Circumstances Interest Rate Subsidies (ECIRS)

Yes/No:

- $\quad$ Other, please state:.

Are you participating in the pilot of drought reform being conducted by the WA and Australian government?

Yes/No:

b) What other farm risk management strategies do you use?

- Store crop and spread sales over the year or longer time Yes/No:

- Farm Management Deposit account (FMD)

Yes/No:

- Credit line with a bank on which you may draw in an emergency (overdraft facility)?

Yes/No:

- Non-farm income (please give detail)

- Yearly income smoothing through grower co-production (Investor backed farming)

AACL (Yes/No):

Other (give detail):

- $\mathrm{CBH}$ Mutual Fund (Yes/No):

End of questions. Thank you. 


\section{Appendix: Data and Regression Output}

Table 1 - Farm Production Data: All Crops

\begin{tabular}{|c|c|c|c|c|c|c|c|}
\hline & $\begin{array}{c}\text { Total Area } \\
\text { Planted }\end{array}$ & Mean Area & Average Yield & $\begin{array}{c}\text { Mean Annual } \\
\text { Yield }\end{array}$ & $\begin{array}{c}\text { St. Dev of } \\
\text { Annual Area } \\
\text { Planted }\end{array}$ & $\begin{array}{c}\text { St. Dev of } \\
\text { Annual Yield }\end{array}$ & $\begin{array}{c}\text { Coefficient of } \\
\text { Variation }\end{array}$ \\
\hline Farm \# & ha & ha & t/ha & t/ha & ha & t/ha & sd/mean \\
\hline 1 & 11,363 & 2,273 & 1.38 & 1.29 & 665 & 0.720 & 0.559 \\
\hline 2 & 7,034 & 1,407 & 1.44 & 1.40 & 192 & 0.593 & 0.423 \\
\hline 3 & 1,017 & 203 & 1.84 & 1.88 & 68 & 0.523 & 0.279 \\
\hline 4 & 11,816 & 2,363 & 1.86 & 1.81 & 402 & 0.839 & 0.465 \\
\hline 5 & 4,662 & 932 & 1.17 & 1.03 & 375 & 0.580 & 0.560 \\
\hline 6 & 21,500 & 4,300 & 1.13 & 1.02 & 1,095 & 0.580 & 0.568 \\
\hline 7 & 10,813 & 2,163 & 1.27 & 1.10 & 1,201 & 0.698 & 0.633 \\
\hline 8 & 5,240 & 1,048 & 1.49 & 1.54 & 169 & 0.936 & 0.607 \\
\hline 9 & 17,010 & 3,402 & 1.37 & 1.44 & 694 & 0.530 & 0.367 \\
\hline 10 & 13,217 & 2,643 & 1.40 & 1.29 & 650 & 0.616 & 0.477 \\
\hline 11 & 31,660 & 6,332 & 1.64 & 1.50 & 2,244 & 0.691 & 0.462 \\
\hline 12 & 30,250 & 6,050 & 1.61 & 1.61 & 0 & 0.603 & 0.373 \\
\hline 13 & 13,822 & 2,764 & 1.78 & 1.73 & 375 & 0.738 & 0.428 \\
\hline 14 & 2,032 & 406 & 1.80 & 1.91 & 96 & 0.789 & 0.414 \\
\hline 15 & 1,089 & 1,089 & 2.03 & 2.07 & 19 & 0.637 & 0.308 \\
\hline 16 & 4,200 & 2,100 & 1.47 & 1.50 & 141 & 0.784 & 0.524 \\
\hline 17 & 3,875 & 775 & 1.26 & 1.28 & 232 & 0.588 & 0.458 \\
\hline 18 & 101,671 & 20,334 & 1.28 & 1.20 & 3,941 & 0.643 & 0.537 \\
\hline 19 & 4,740 & 948 & 1.24 & 1.30 & 207 & 0.703 & 0.540 \\
\hline
\end{tabular}

Notes: All figures use five years of data from 2006 to 2010. Average yield = total tonnes from 2006 to 2010/total hectares planted from 2006 to 2010. 
Table 2 - Farm Production Data: Wheat

\begin{tabular}{|c|c|c|c|c|c|c|c|}
\hline & $\begin{array}{c}\text { Total Area } \\
\text { Planted }\end{array}$ & Mean Area & Average Yield & $\begin{array}{c}\text { Mean Annual } \\
\text { Yield }\end{array}$ & $\begin{array}{c}\text { St. Dev of } \\
\text { Annual Area } \\
\text { Planted }\end{array}$ & $\begin{array}{c}\text { St. Dev of } \\
\text { Annual Yield }\end{array}$ & $\begin{array}{c}\text { Coefficient of } \\
\text { Variation }\end{array}$ \\
\cline { 2 - 8 } Farm \# & ha & ha & t/ha & t/ha & ha & t/ha & sd/mean \\
\hline 1 & 8,081 & 1,616 & 1.50 & 1.39 & 424 & 0.644 & 0.464 \\
\hline 2 & 5,713 & 1,143 & 1.37 & 1.37 & 144 & 0.575 & 0.420 \\
\hline 3 & 130 & 65 & 2.20 & 2.20 & 0 & 1.273 & 0.579 \\
\hline 4 & 5,562 & 1,112 & 2.20 & 2.09 & 210 & 0.876 & 0.420 \\
\hline 5 & 3,992 & 798 & 1.22 & 1.12 & 267 & 0.658 & 0.588 \\
\hline 6 & 21,500 & 4,300 & 1.13 & 1.02 & 1,095 & 0.698 & 0.684 \\
\hline 7 & 8,769 & 1,754 & 1.41 & 1.18 & 1,208 & 0.925 & 0.787 \\
\hline 8 & 3,200 & 640 & 1.54 & 1.52 & 54 & 0.482 & 0.317 \\
\hline 9 & 11,732 & 2,346 & 1.50 & 1.57 & 420 & 0.587 & 0.373 \\
\hline 10 & 12,235 & 2,447 & 1.39 & 1.30 & 473 & 0.617 & 0.475 \\
\hline 11 & 21,475 & 4,295 & 1.83 & 1.65 & 1,511 & 0.768 & 0.467 \\
\hline 12 & 25,500 & 5,100 & 1.68 & 1.68 & 0 & 0.626 & 0.373 \\
\hline 13 & 8,349 & 1,670 & 2.08 & 1.98 & 375 & 0.774 & 0.391 \\
\hline 14 & 110 & 55 & 1.75 & 1.78 & 4 & 0.742 & 0.418 \\
\hline 15 & na & na & na & na & na & na & na \\
\hline 16 & 3,000 & 1,500 & 1.45 & 1.45 & 0 & 0.495 & 0.341 \\
\hline 17 & 2,400 & 480 & 1.35 & 1.36 & 157 & 0.567 & 0.415 \\
\hline 18 & 101,671 & 20,334 & 1.28 & 1.20 & 3,941 & 0.643 & 0.537 \\
\hline 19 & 2,949 & 590 & 1.36 & 1.43 & 137 & 0.900 & 0.628 \\
\hline
\end{tabular}

Notes: See Table 1. 
Table 3 - Panel Set of Yearly Production

\begin{tabular}{|c|c|c|c|c|c|c|c|c|c|c|c|}
\hline \multirow{2}{*}{$\begin{array}{c}\text { Farm } \\
\#\end{array}$} & \multirow{2}{*}{ Year } & \multicolumn{2}{|c|}{ All Crops } & \multicolumn{2}{|c|}{ Wheat } & \multicolumn{2}{|c|}{ Barley } & \multicolumn{2}{|c|}{ Canola } & \multicolumn{2}{|c|}{ Lupins } \\
\hline & & t/ha & ha & t/ha & ha & t/ha & ha & t/ha & ha & t/ha & ha \\
\hline \multirow{5}{*}{1} & 2006 & 0.81 & 1975 & 0.98 & 1510 & 0.00 & 0 & 0.00 & 0 & 0.21 & 315 \\
\hline & 2007 & 0.61 & 1270 & 0.67 & 918 & 0.70 & 152 & 0.00 & 0 & 0.00 & 0 \\
\hline & 2008 & 2.38 & 2501 & 2.33 & 1919 & 2.93 & 305 & 0.00 & 0 & 2.55 & 122 \\
\hline & 2009 & 1.63 & 2655 & 1.67 & 1914 & 1.97 & 290 & 0.00 & 0 & 1.36 & 321 \\
\hline & 2010 & 1.02 & 2962 & 1.29 & 1820 & 0.60 & 15 & 0.51 & 422 & 0.64 & 555 \\
\hline \multirow{5}{*}{2} & 2006 & 1.87 & 1320 & 1.81 & 1068 & 2.13 & 252 & 0.00 & 0 & 0.00 & 0 \\
\hline & 2007 & 1.66 & 1522 & 1.60 & 1318 & 2.08 & 204 & 0.00 & 0 & 0.00 & 0 \\
\hline & 2008 & 1.68 & 1439 & 1.68 & 989 & 1.69 & 450 & 0.00 & 0 & 0.00 & 0 \\
\hline & 2009 & 1.40 & 1625 & 1.37 & 1275 & 1.51 & 350 & 0.00 & 0 & 0.00 & 0 \\
\hline & 2010 & 0.38 & 1128 & 0.38 & 1063 & 0.43 & 65 & 0.00 & 0 & 0.00 & 0 \\
\hline \multirow{5}{*}{3} & 2006 & 1.90 & 94 & 0.00 & 0 & 0.00 & 0 & 0.00 & 0 & 0.00 & 0 \\
\hline & 2007 & 2.63 & 190 & 0.00 & 0 & 2.90 & 60 & 1.70 & 60 & 0.00 & 0 \\
\hline & 2008 & 1.76 & 230 & 0.00 & 0 & 2.10 & 50 & 1.10 & 120 & 0.00 & 0 \\
\hline & 2009 & 1.92 & 273 & 3.10 & 65 & 2.30 & 38 & 0.80 & 120 & 0.00 & 0 \\
\hline & 2010 & 1.16 & 230 & 1.30 & 65 & 1.40 & 45 & 0.00 & 0 & 0.00 & 0 \\
\hline \multirow{5}{*}{4} & 2006 & 1.31 & 2000 & 1.40 & 800 & 2.00 & 600 & 0.00 & 0 & 0.50 & 600 \\
\hline & 2007 & 0.85 & 1970 & 1.20 & 1000 & 0.81 & 370 & 0.00 & 0 & 0.30 & 600 \\
\hline & 2008 & 2.60 & 2290 & 2.80 & 1250 & 3.26 & 460 & 1.83 & 30 & 1.64 & 550 \\
\hline & 2009 & 2.77 & 2706 & 3.20 & 1312 & 3.18 & 471 & 1.64 & 366 & 2.15 & 557 \\
\hline & 2010 & 1.49 & 2850 & 1.83 & 1200 & 2.00 & 550 & 0.82 & 550 & 0.91 & 550 \\
\hline \multirow{5}{*}{5} & 2006 & 0.73 & 536 & 0.73 & 536 & 0.00 & 0 & 0.00 & 0 & 0.00 & 0 \\
\hline & 2007 & 0.20 & 582 & 0.20 & 582 & 0.00 & 0 & 0.00 & 0 & 0.00 & 0 \\
\hline & 2008 & 1.46 & 959 & 1.68 & 740 & 0.82 & 170 & 0.43 & 49 & 0.00 & 0 \\
\hline & 2009 & 1.63 & 1185 & 1.76 & 959 & 1.14 & 146 & 1.02 & 80 & 0.00 & 0 \\
\hline & 2010 & 1.15 & 1400 & 1.23 & 1175 & 1.03 & 135 & 0.23 & 90 & 0.00 & 0 \\
\hline \multirow{5}{*}{6} & 2006 & 0.30 & 4000 & 0.30 & 4000 & 0.00 & 0 & 0.00 & 0 & 0.00 & 0 \\
\hline & 2007 & 0.40 & 2500 & 0.40 & 2500 & 0.00 & 0 & 0.00 & 0 & 0.00 & 0 \\
\hline & 2008 & 2.00 & 5000 & 2.00 & 5000 & 0.00 & 0 & 0.00 & 0 & 0.00 & 0 \\
\hline & 2009 & 1.30 & 5000 & 1.30 & 5000 & 0.00 & 0 & 0.00 & 0 & 0.00 & 0 \\
\hline & 2010 & 1.10 & 5000 & 1.10 & 5000 & 0.00 & 0 & 0.00 & 0 & 0.00 & 0 \\
\hline \multirow{5}{*}{7} & 2006 & 0.39 & 957 & 0.54 & 578 & 0.00 & 0 & 0.00 & 0 & 0.08 & 180 \\
\hline & 2007 & 0.13 & 1140 & 0.21 & 581 & 0.10 & 284 & 0.00 & 0 & 0.00 & 75 \\
\hline & 2008 & 2.41 & 1878 & 2.50 & 1625 & 2.33 & 121 & 0.00 & 0 & 0.89 & 56 \\
\hline & 2009 & 1.67 & 3300 & 1.70 & 2980 & 1.56 & 222 & 0.00 & 0 & 0.00 & 0 \\
\hline & 2010 & 0.91 & 3538 & 0.93 & 3005 & 1.30 & 140 & 0.00 & 0 & 0.43 & 240 \\
\hline \multirow{5}{*}{8} & 2006 & 2.03 & 900 & 2.00 & 600 & 2.10 & 300 & 0.00 & 0 & 0.00 & 0 \\
\hline & 2007 & 1.83 & 1000 & 1.80 & 700 & 1.90 & 300 & 0.00 & 0 & 0.00 & 0 \\
\hline & 2008 & 1.89 & 1000 & 1.80 & 700 & 2.10 & 300 & 0.00 & 0 & 0.00 & 0 \\
\hline & 2009 & 1.11 & 1000 & 1.00 & 600 & 1.50 & 300 & 0.60 & 100 & 0.00 & 0 \\
\hline & 2010 & 0.84 & 1340 & 1.00 & 600 & 1.20 & 300 & 0.32 & 200 & 0.43 & 240 \\
\hline
\end{tabular}




\begin{tabular}{|c|c|c|c|c|c|c|c|c|c|c|c|}
\hline \multirow{5}{*}{9} & 2006 & 1.46 & 2694 & 1.59 & 2037 & 1.73 & 213 & 0.56 & 248 & 0.99 & 196 \\
\hline & 2007 & 2.28 & 2710 & 2.45 & 1781 & 2.74 & 303 & 1.27 & 203 & 1.68 & 423 \\
\hline & 2008 & 1.32 & 3521 & 1.33 & 2512 & 1.08 & 374 & 1.25 & 270 & 1.53 & 365 \\
\hline & 2009 & 1.43 & 3807 & 1.64 & 2617 & 1.59 & 290 & 0.63 & 543 & 0.90 & 357 \\
\hline & 2010 & 0.73 & 4278 & 0.84 & 2785 & 0.91 & 337 & 0.30 & 711 & 0.58 & 445 \\
\hline \multirow{5}{*}{10} & 2006 & 0.74 & 1900 & 0.74 & 1900 & 0.00 & 0 & 0.00 & 0 & 0.00 & 0 \\
\hline & 2007 & 0.66 & 1982 & 0.66 & 1982 & 0.00 & 0 & 0.00 & 0 & 0.00 & 0 \\
\hline & 2008 & 2.10 & 3209 & 2.10 & 2915 & 2.06 & 294 & 0.00 & 0 & 0.00 & 0 \\
\hline & 2009 & 1.70 & 3181 & 1.70 & 2803 & 1.67 & 378 & 0.00 & 0 & 0.00 & 0 \\
\hline & 2010 & 1.26 & 2945 & 1.29 & 2635 & 0.00 & 0 & 0.00 & 0 & 1.00 & 310 \\
\hline \multirow{5}{*}{11} & 2006 & 0.89 & 3167 & 0.98 & 2185 & 1.08 & 437 & 0.00 & 0 & 0.38 & 545 \\
\hline & 2007 & 0.74 & 4920 & 0.72 & 3280 & 0.78 & 1498 & 0.00 & 0 & 0.63 & 142 \\
\hline & 2008 & 2.30 & 6993 & 2.40 & 4920 & 2.70 & 745 & 1.68 & 758 & 1.75 & 570 \\
\hline & 2009 & 2.06 & 8409 & 2.33 & 5810 & 2.53 & 260 & 1.00 & 1257 & 1.70 & 972 \\
\hline & 2010 & 1.50 & 8171 & 1.80 & 5280 & 1.87 & 407 & 0.57 & 1392 & 1.13 & 850 \\
\hline \multirow{5}{*}{12} & 2006 & 1.34 & 6050 & 1.40 & 5100 & 1.40 & 100 & 0.00 & 0 & 1.00 & 850 \\
\hline & 2007 & 0.95 & 6050 & 1.00 & 5100 & 1.00 & 100 & 0.00 & 0 & 0.63 & 850 \\
\hline & 2008 & 2.48 & 6050 & 2.60 & 5100 & 2.50 & 100 & 0.00 & 0 & 1.75 & 850 \\
\hline & 2009 & 1.96 & 6050 & 2.00 & 5100 & 2.00 & 100 & 0.00 & 0 & 1.70 & 850 \\
\hline & 2010 & 1.35 & 6050 & 1.40 & 5100 & 1.50 & 100 & 0.00 & 0 & 1.00 & 850 \\
\hline \multirow{5}{*}{13} & 2006 & 0.96 & 2583 & 1.21 & 1470 & 1.04 & 440 & 0.00 & 0 & 0.38 & 673 \\
\hline & 2007 & 1.11 & 2273 & 1.26 & 1133 & 0.98 & 700 & 0.00 & 0 & 0.91 & 440 \\
\hline & 2008 & 2.76 & 2946 & 3.05 & 1761 & 2.59 & 650 & 0.00 & 0 & 2.02 & 535 \\
\hline & 2009 & 2.10 & 3268 & 2.35 & 2088 & 1.84 & 289 & 1.22 & 325 & 1.84 & 566 \\
\hline & 2010 & 1.69 & 2752 & 2.04 & 1897 & 0.00 & 0 & 0.69 & 330 & 1.17 & 450 \\
\hline \multirow{5}{*}{14} & 2006 & 1.95 & 285 & 0.00 & 0 & 2.40 & 60 & 1.10 & 107 & 0.00 & 0 \\
\hline & 2007 & 2.96 & 337 & 0.00 & 0 & 3.70 & 100 & 1.35 & 87 & 0.00 & 0 \\
\hline & 2008 & 2.16 & 416 & 0.00 & 0 & 3.00 & 141 & 1.20 & 185 & 0.00 & 0 \\
\hline & 2009 & 1.70 & 482 & 2.30 & 52 & 2.40 & 140 & 0.95 & 240 & 0.00 & 0 \\
\hline & 2010 & 0.78 & 512 & 1.25 & 58 & 1.15 & 171 & 0.18 & 133 & 0.00 & 0 \\
\hline \multirow{5}{*}{15} & 2006 & 2.46 & 215 & 0.00 & 0 & 2.30 & 45 & 0.00 & 0 & 0.00 & 0 \\
\hline & 2007 & 2.68 & 200 & 0.00 & 0 & 2.20 & 40 & 0.00 & 0 & 0.00 & 0 \\
\hline & 2008 & 2.29 & 210 & 0.00 & 0 & 1.80 & 40 & 0.00 & 0 & 0.00 & 0 \\
\hline & 2009 & 1.85 & 214 & 0.00 & 0 & 1.60 & 50 & 1.50 & 24 & 0.00 & 0 \\
\hline & 2010 & 1.07 & 250 & 0.00 & 0 & 1.50 & 24 & 0.28 & 62 & 0.00 & 0 \\
\hline \multirow{5}{*}{16} & 2006 & na & na & na & na & na & na & na & na & na & na \\
\hline & 2007 & na & na & na & na & na & na & na & na & na & na \\
\hline & 2008 & na & na & na & na & na & na & na & na & na & na \\
\hline & 2009 & 2.05 & 2000 & 1.80 & 1500 & 0.00 & 0 & 0.00 & 0 & 1.00 & 200 \\
\hline & 2010 & 0.94 & 2200 & 1.10 & 1500 & 0.00 & 0 & 0.00 & 0 & 0.60 & 300 \\
\hline \multirow{5}{*}{17} & 2006 & 0.93 & 430 & 1.05 & 230 & 1.05 & 80 & 0.50 & 40 & 0.00 & 0 \\
\hline & 2007 & 2.08 & 681 & 2.10 & 420 & 2.20 & 95 & 1.60 & 40 & 1.10 & 40 \\
\hline & 2008 & 1.42 & 800 & 1.51 & 580 & 1.00 & 120 & 1.00 & 60 & 0.00 & 0 \\
\hline & 2009 & 1.46 & 964 & 1.56 & 570 & 1.76 & 215 & 0.40 & 40 & 0.50 & 84 \\
\hline & 2010 & 0.52 & 1000 & 0.60 & 600 & 0.50 & 200 & 0.25 & 80 & 0.20 & 60 \\
\hline
\end{tabular}




\begin{tabular}{|c|c|c|c|c|c|c|c|c|c|c|c|}
\hline \multirow{5}{*}{18} & 2006 & 0.86 & 19926 & 0.86 & 19926 & 0.00 & 0 & 0.00 & 0 & 0.00 & 0 \\
\hline & 2007 & 0.56 & 18380 & 0.56 & 18380 & 0.00 & 0 & 0.00 & 0 & 0.00 & 0 \\
\hline & 2008 & 2.14 & 24000 & 2.14 & 24000 & 0.00 & 0 & 0.00 & 0 & 0.00 & 0 \\
\hline & 2009 & 1.56 & 24365 & 1.56 & 24365 & 0.00 & 0 & 0.00 & 0 & 0.00 & 0 \\
\hline & 2010 & 0.87 & 15000 & 0.87 & 15000 & 0.00 & 0 & 0.00 & 0 & 0.00 & 0 \\
\hline \multirow{5}{*}{19} & 2006 & 1.56 & 681 & 1.65 & 497 & 2.40 & 63 & 0.76 & 121 & 0.00 & 0 \\
\hline & 2007 & 2.14 & 995 & 2.41 & 705 & 2.55 & 58 & 1.20 & 232 & 0.00 & 0 \\
\hline & 2008 & 0.79 & 1222 & 0.44 & 709 & 2.03 & 116 & 1.06 & 397 & 0.00 & 0 \\
\hline & 2009 & 1.64 & 817 & 2.12 & 397 & 2.66 & 60 & 0.93 & 360 & 0.00 & 0 \\
\hline & 2010 & 0.39 & 1025 & 0.55 & 641 & 0.00 & 0 & 0.11 & 384 & 0.00 & 0 \\
\hline
\end{tabular}


Table 4 - Insurance Data

\begin{tabular}{|c|c|c|c|c|c|c|c|c|c|c|}
\hline & \multicolumn{9}{|c|}{ Hail and Fire Insurance } & \multirow{3}{*}{$\begin{array}{c}\begin{array}{c}\text { Uninsurable } \\
\text { Risk }\end{array} \\
\text { Max Willing } \\
\text { to Pay for } \\
\text { Insurance } \\
\% \text { of } \\
\text { Expected } \\
\text { Crop Revenue }\end{array}$} \\
\hline & \multicolumn{2}{|c|}{ Premium paid } & \multicolumn{2}{|c|}{ Coverage } & \multirow{2}{*}{$\begin{array}{c}\text { Highest } \\
\text { Premium } \\
\text { Willing to } \\
\text { Pay } \\
\text { \% of } \\
\text { Expected } \\
\text { Crop Revenue }\end{array}$} & \multicolumn{3}{|c|}{ Claims (Ten Years) } & \multirow{2}{*}{$\begin{array}{c}\text { Loss } \\
\text { Ratio } \\
\%\end{array}$} & \\
\hline Farm \# & $\$$ & $\begin{array}{c}\text { \% of } \\
\text { Expected } \\
\text { Crop Revenue }\end{array}$ & \$ Coverage & $\begin{array}{c}\text { \% of } \\
\text { Expected } \\
\text { Crop Revenue }\end{array}$ & & Number & \$ Received & $\begin{array}{l}\text { Unclaimed } \\
\text { Losses }\end{array}$ & & \\
\hline 1 & 8,500 & 0.90 & 951,905 & 100 & 1.50 & 2 & 15,330 & 0 & 7.6 & na \\
\hline 2 & na & 0.60 & na & 100 & 0.88 & 1 & 30,000 & 0 & $\mathrm{Na}$ & 1 \\
\hline 3 & 1,200 & 1.00 & 120,000 & 95 & 1.50 & 1 & 8,600 & 0 & 71.7 & 0 \\
\hline 4 & 16,000 & 0.80 & $2,000,000$ & 100 & 0.80 & 2 & 9,000 & 0 & 48.5 & 0 \\
\hline 5 & 2,000 & 0.50 & 600,000 & 100 & 0.50 & 0 & 0 & 0 & 0.0 & 0.5 \\
\hline 6 & 15,000 & 1.00 & $1,400,000$ & 100 & 10.00 & 1 & 10,000 & 0 & 6.7 & 10 \\
\hline 7 & 9,000 & 1.00 & $1,300,000$ & 100 & 1.00 & 0 & 0 & 1 & 0.0 & 2 \\
\hline 8 & 3,600 & 0.60 & 600,000 & 100 & 0.70 & 0 & 0 & 0 & 0.0 & 1 \\
\hline 9 & 6,400 & 0.50 & $1,280,000$ & 100 & na & 1 & 40,000 & 0 & 62.5 & 2 \\
\hline 10 & 12,000 & 0.60 & $2,000,000$ & 100 & 2.00 & 1 & 27,000 & 0 & 22.5 & na \\
\hline 11 & 35,000 & 1.00 & $3,500,000$ & 80 & 1.00 & 1 & 32,000 & 0 & 9.1 & 0 \\
\hline 12 & 0 & 0.00 & 0 & 0 & 5.00 & 0 & 0 & 0 & $\mathrm{Na}$ & na \\
\hline 13 & 15,000 & 1.00 & $1,500,000$ & 100 & na & 0 & 0 & 0 & 0.0 & 0 \\
\hline 14 & na & 0.70 & na & 100 & na & 0 & 0 & 1 & $\mathrm{Na}$ & 1 \\
\hline 15 & 600 & 2.00 & 300,000 & 100 & 5.00 & 1 & 2,000 & 0 & 33.3 & 1 \\
\hline 16 & 0 & 0.00 & 0 & 0 & 0.00 & 0 & 0 & 0 & $\mathrm{Na}$ & 10 \\
\hline 17 & 1,000 & 0.66 & 150,000 & 100 & 0.66 & 0 & 0 & 0 & 0.0 & 0 \\
\hline 18 & 80,000 & 1.00 & $8,000,000$ & 100 & 1.00 & 2 & 13,000 & 0 & 1.6 & na \\
\hline 19 & 2,130 & 0.49 & 350,000 & 80 & 0.53 & 1 & na & 1 & na & na \\
\hline
\end{tabular}


Notes:

All figures are for one year, except for claims data which is a record of the past ten years.

Highest Premium Willing to Pay: Farmers were asked for maximum amount they would be willing to pay for their existing insurance policy. Unclaimed losses: Losses caused by insurable events like hail and fire that were not claimed due to lack of insurance or other reason.

Uninsurable Risk: Farmers were asked for the maximum premium they would be willing to pay for insurance against drought, frost and flood.

Loss Ratio $=(\$$ Claims received $/(\$$ yearly premium*10 $)) * 100$ 
Table 5 - Insurance Summary Statistics

\begin{tabular}{|c|c|c|c|c|c|c|c|c|c|c|}
\hline & \multicolumn{2}{|c|}{ Premium paid } & \multicolumn{2}{|c|}{ Coverage } & \multirow{2}{*}{$\begin{array}{l}\text { Highest } \\
\text { Premium } \\
\text { Willing } \\
\text { to Pay } \\
\text { \% of } \\
\text { expected } \\
\text { crop }\end{array}$} & \multicolumn{3}{|c|}{ Claims (past ten years) } & \multirow{2}{*}{$\begin{array}{c}\text { Loss } \\
\text { Ratio } \\
\%\end{array}$} & \multirow{2}{*}{$\begin{array}{c}\text { Maximum } \\
\text { Willing to } \\
\text { Pay for } \\
\text { Drought } \\
\text { Insurance } \\
\% \text { of } \\
\text { expected } \\
\text { crop }\end{array}$} \\
\hline & $\$$ & $\begin{array}{c}\% \text { of } \\
\text { expected } \\
\text { crop }\end{array}$ & $\begin{array}{c}\$ \\
\text { coverage }\end{array}$ & $\begin{array}{c}\% \text { of } \\
\text { expected } \\
\text { crop }\end{array}$ & & Number & $\begin{array}{c}\$ \\
\text { Received }\end{array}$ & $\begin{array}{c}\text { Unclaimed } \\
\text { Losses }\end{array}$ & & \\
\hline $\mathrm{n}$ & 17 & 17 & 18 & 19 & 16 & 19 & 18 & 19 & 14 & 14 \\
\hline Mean & 12,202 & 0.75 & $1,414,818$ & 87.1 & 2.00 & 0.7 & 10,385 & 0.2 & 16.5 & 2 \\
\hline St. Dev & 19,625 & 0.43 & $1,930,590$ & 31.3 & 2.58 & 0.7 & 13,228 & 0.4 & 23.8 & 3 \\
\hline Median & 6,400 & 0.70 & 951,905 & 100.0 & 1.00 & 1.0 & 5,300 & 0.0 & 6.2 & 1 \\
\hline Min & 0 & 0.00 & 0 & 0.0 & 0.00 & 0.0 & 0 & 0.0 & 0.00 & 0 \\
\hline Max & 80,000 & 2.00 & $8,000,000$ & 100.0 & 10.00 & 2.0 & 40,000 & 1.0 & 71.7 & 10 \\
\hline
\end{tabular}




\section{Econometric Work}

\section{Risk Aversion}

*RATS Program:

allocate 19

open data

data(format=XLS,org=col) / postcd farmarea croparea wheatprod wheatyield wheatprodsd \$ wheatyieldsd hedge forward insprmpct wlpins claimsdls wtpunins ecpay ecirs pilot \$ sellyear fmd crdline nonfarminc cbh

print / postcd farmarea croparea wheatprod wheatyield wheatprodsd \$

wheatyieldsd hedge forward insprmpct wlpins claimsdls wtpunins ecpay ecirs pilot \$ sellyear fmd crdline nonfarminc cbh

set coefvar $=$ wheatyieldsd/wheatyield

set coefvarsq $=$ coefvar $^{\wedge} 2$

print / coefvar coefvarsq

linreg(robusterrors) insprmpct / residual1

\# constant coefvarsq ecirs

print / residual1

compute cutoff $=3 * \operatorname{sqrt}(\%$ seesq)

linreg(robusterrors,smpl=abs(residual1)<cutoff) insprmpct / residual2

\# constant coefvarsq

print / residual2

*RATS Output:

$\begin{array}{ccc}\text { ENTRY } & \text { COEFVAR } & \text { COEFVARSQ } \\ 1 & 0.463904899135 & 0.215207755442 \\ 2 & 0.420321637427 & 0.176670278889 \\ 3 & 0.578545454545 & 0.334714842975 \\ 4 & 0.420000958359 & 0.176400805023 \\ 5 & 0.587857142857 & 0.345576020408 \\ 6 & 0.684215686275 & 0.468151105344 \\ 7 & 0.786904761905 & 0.619219104308 \\ 8 & 0.316907894737 & 0.100430613747 \\ 9 & 0.373329940196 & 0.139375244247 \\ 10 & 0.475423728814 & 0.226027721919 \\ 11 & 0.466767922236 & 0.217872293228 \\ 12 & 0.372678571429 & 0.138889317602 \\ 13 & 0.390565085772 & 0.152541086224\end{array}$




$\begin{array}{lll}14 & 0.418309859155 & 0.174983138266 \\ 15 & \text { NA } & \text { NA } \\ 16 & 0.341361894366 & 0.116527942925 \\ 17 & 0.415327595459 & 0.172497011550 \\ 18 & 0.537160580151 & 0.288541488868 \\ 19 & 0.627549198466 & 0.393817996495\end{array}$

*Including ECIRS variable:

Linear Regression - Estimation by Least Squares

With Heteroscedasticity-Consistent (Eicker-White) Standard Errors

Dependent Variable INSPRMPCT

Usable Observations 18

Degrees of Freedom 15

Total Observations 19

Skipped/Missing 1

Centered $\mathrm{R}^{* * 2} \quad 0.252500$

$\mathrm{R} \mathrm{Bar} * * 2 \quad 0.152833$

Uncentered $\mathrm{R}^{* * 2} \quad 0.873755$

$\mathrm{T} \times \mathrm{R}^{* * 2} \quad 15.728$

Mean of Dependent Variable $\quad 0.6856611111$

Std Error of Dependent Variable $\quad 0.3180483262$

Standard Error of Estimate $\quad 0.2927369466$

Sum of Squared Residuals $\quad 1.2854237985$

Log Likelihood

Durbin-Watson Statistic $\quad 2.618618$

\begin{tabular}{|c|c|c|c|c|}
\hline Variable & Coeff & Std Error & T-Stat & Signif \\
\hline & & & & \\
\hline 2. COEFVARSQ & 1.339585472 & 0.470012674 & 2.85011 & 0.00437048 \\
\hline 3. ECIRS & -0.222801800 & 0.123261739 & -1.80755 & 0.07067651 \\
\hline
\end{tabular}

\begin{tabular}{cr} 
ENTRY & \multicolumn{1}{c}{ RESIDUAL1 } \\
1 & 0.213545345885 \\
2 & -0.027730410408 \\
3 & 0.160555387659 \\
4 & 0.172630572868 \\
5 & -0.131192288066 \\
6 & -0.018193890809 \\
7 & 0.002239412308 \\
8 & 0.074399137385 \\
9 & -0.077770523834 \\
10 & 0.128952875758 \\
11 & 0.317075969778 \\
12 & -0.577119583561 \\
13 & 0.404592705530 \\
14 & 0.074529658659
\end{tabular}




$\begin{array}{ll}15 & \text { NA } \\ 16 & -0.547164610916 \\ 17 & 0.037860037889 \\ 18 & 0.222408542002 \\ 19 & -0.429618338128\end{array}$

*Not including ECIRS variable:

Linear Regression - Estimation by Least Squares

With Heteroscedasticity-Consistent (Eicker-White) Standard Errors

Dependent Variable INSPRMPCT

Usable Observations 18

Degrees of Freedom 16

Total Observations 19

Skipped/Missing 1

Centered $\mathrm{R}^{* * 2} \quad 0.198329$

$\mathrm{R}$ Bar $* * 2 \quad 0.148225$

Uncentered $\mathrm{R} * * 2$

$\mathrm{T} \times \mathrm{R}^{* * 2} 2 \quad 15.563$

Mean of Dependent Variable $\quad 0.6856611111$

Std Error of Dependent Variable $\quad 0.3180483262$

Standard Error of Estimate $\quad 0.2935320636$

Sum of Squared Residuals $\quad 1.3785771574$

Log Likelihood $\quad-2.41702$

Durbin-Watson Statistic $\quad 2.785509$

\begin{tabular}{|c|c|c|c|c|}
\hline Variable & Coeff & Std Error & T-Stat & Signif \\
\hline 1. Constan & 0.4307271262 & 0.1391445300 & 3.09554 & 0.00196456 \\
\hline 2. COEFVARSQ & 1.0294715915 & 0.3941417030 & 2.61193 & 0.00900320 \\
\hline
\end{tabular}

\begin{tabular}{cr} 
ENTRY & \multicolumn{1}{c}{ RESIDUAL2 } \\
1 & 0.240622603352 \\
2 & -0.012604159329 \\
3 & 0.224693451755 \\
4 & 0.187673256361 \\
5 & -0.286487821862 \\
6 & 0.087324610372 \\
7 & -0.068195602945 \\
8 & 0.065882410080 \\
9 & -0.074209980661 \\
10 & -0.063416244757 \\
11 & 0.344979537397 \\
12 & -0.573709732985 \\
13 & 0.412236159045 \\
14 & 0.089132704013 \\
15 & NA \\
16 & -0.550689333008
\end{tabular}


$17 \quad 0.051692100841$

$18 \quad 0.272227608092$

$19-0.347151565761$

\section{Moral Hazard}

*Panel regression

calendar(panelobs=5,a) 2006:1

allocate 19//2010:1

open data

data(format=excel,org=col) / allcropsyield allcropsarea wheatyield wheatarea \$ barleyyield barleyarea

print / allcropsyield allcropsarea wheatyield wheatarea \$

barleyyield barleyarea

* pregress is panel data regression

* fixed effects: the intercept is dropped from the fixed effects regression as it is

* wiped out as a time-invariant variable

\section{*ALLCROPS}

pregress(method=fixed) allcropsarea

\# allcropsyield

*WHEAT

pregress(method=fixed) wheatarea

\# wheatyield

*BARLEY

pregress(method=fixed) barleyarea

\# barleyyield 


\section{RATS Output:}

\section{*ALLCROPS}

Panel Regression - Estimation by Fixed Effects

Dependent Variable ALLCROPSAREA

\begin{tabular}{|c|c|}
\hline Panel(5) of Annual Data From & 1//2006:01 То \\
\hline Usable Observations & 95 \\
\hline Degrees of Freedom & 75 \\
\hline Centered $\mathrm{R} * * 2$ & 0.953878 \\
\hline $\mathrm{R}$ Bar **2 & 0.942194 \\
\hline Uncentered $\mathrm{R} * * 2$ & 0.968775 \\
\hline $\mathrm{T} \times \mathrm{R} * * 2$ & 92.034 \\
\hline Mean of Dependent Variable & 3132.1157895 \\
\hline Std Error of Dependent Variable & 4558.5689894 \\
\hline Standard Error of Estimate & 1096.0125780 \\
\hline Sum of Squared Residuals & 90093267.841 \\
\hline Regression $\mathrm{F}(19,75)$ & 81.6381 \\
\hline Significance Level of F & 0.00000000 \\
\hline Log Likelihood & -788.51692 \\
\hline
\end{tabular}

Variable Coeff Std Error T-Stat Signif

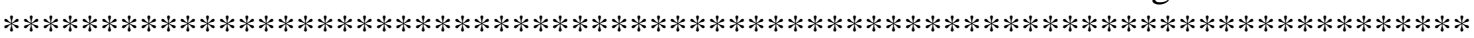

1. ALLCROPSYIELD $\quad 557.15001040 \quad 186.07010747 \quad 2.99430 \quad 0.00372464$

*WHEAT

Panel Regression - Estimation by Fixed Effects

Dependent Variable WHEATAREA

Panel(5) of Annual Data From 1//2006:01 To

Usable Observations

95

Degrees of Freedom

75

Centered $\mathrm{R} * * 2$

0.960429

$\mathrm{R}$ Bar **2

0.950405

Uncentered $\mathrm{R} * * 2$

0.970186

$\mathrm{T} \times \mathrm{R} * * 2$

92.168

Mean of Dependent Variable

2592.8105263

Std Error of Dependent Variable

4556.4170164

Standard Error of Estimate

1014.7133843

Sum of Squared Residuals

77223243.926

Regression $\mathrm{F}(19,75)$

95.8076

Significance Level of F

0.00000000

Log Likelihood

$-781.19503$

Variable Coeff Std Error T-Stat Signif

$* * * * * * * * * * * * * * * * * * * * * * * * * * * * * * * * * * * * * * * * * * * * * * * * * * * * * * * * * * * * * * * * * * * * * * * * * * * * * *$

$\begin{array}{lllll}\text { 1. WHEATYIELD } 434.25926100 & 152.12673808 & 2.85459 & 0.00556907\end{array}$ 


\section{* BARLEY}

Panel Regression - Estimation by Fixed Effects Dependent Variable BARLEYAREA

\begin{tabular}{|c|c|}
\hline Panel(5) of Annual Data From & 1//2006:01 То \\
\hline Usable Observations & 95 \\
\hline Degrees of Freedom & 75 \\
\hline Centered $\mathrm{R}^{* * 2}$ & 0.626816 \\
\hline $\mathrm{R} \operatorname{Bar} * * 2$ & 0.532276 \\
\hline Uncentered $\mathrm{R}^{* * 2}$ & 0.784504 \\
\hline $\mathrm{T} \times \mathrm{R} * * 2$ & 74.528 \\
\hline Mean of Dependent Variable & 189.44210526 \\
\hline Std Error of Dependent Variable & 222.63550575 \\
\hline Standard Error of Estimate & 152.26127946 \\
\hline Sum of Squared Residuals & 1738762.2916 \\
\hline Regression $\mathrm{F}(19,75)$ & 6.6302 \\
\hline Significance Level of F & 0.00000000 \\
\hline Log Likelihood & -601.00250 \\
\hline
\end{tabular}

Variable Coeff Std Error T-Stat Signif

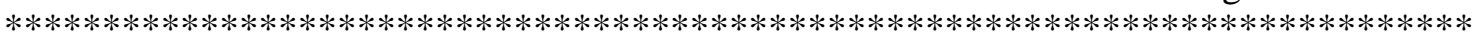

$\begin{array}{lllll}\text { 1. BARLEYYIELD } 36.292489097 & 21.834312161 & 1.66218 & 0.10065165\end{array}$ 


\section{ECONOMICS DISCUSSION PAPERS}

\section{0}

\begin{tabular}{|c|c|c|}
\hline $\begin{array}{l}\text { DP } \\
\text { NUMBER }\end{array}$ & AUTHORS & TITLE \\
\hline 10.01 & Hendry, D.F. & $\begin{array}{l}\text { RESEARCH AND THE ACADEMIC: A TALE OF } \\
\text { TWO CULTURES }\end{array}$ \\
\hline 10.02 & McLure, M., Turkington, D. and Weber, E.J. & A CONVERSATION WITH ARNOLD ZELLNER \\
\hline 10.03 & $\begin{array}{l}\text { Butler, D.J., Burbank, V.K. and } \\
\text { Chisholm, J.S. }\end{array}$ & $\begin{array}{l}\text { THE FRAMES BEHIND THE GAMES: PLAYER'S } \\
\text { PERCEPTIONS OF PRISONER'S DILEMMA, } \\
\text { CHICKEN, DICTATOR, AND ULTIMATUM GAMES }\end{array}$ \\
\hline 10.04 & Harris, R.G., Robertson, P.E. and Xu, J.Y. & $\begin{array}{l}\text { THE INTERNATIONAL EFFECTS OF CHINA'S } \\
\text { GROWTH, TRADE AND EDUCATION BOOMS }\end{array}$ \\
\hline 10.05 & Clements, K.W., Mongey, S. and Si, J. & $\begin{array}{l}\text { THE DYNAMICS OF NEW RESOURCE PROJECTS } \\
\text { A PROGRESS REPORT }\end{array}$ \\
\hline 10.06 & Costello, G., Fraser, P. and Groenewold, N. & $\begin{array}{l}\text { HOUSE PRICES, NON-FUNDAMENTAL } \\
\text { COMPONENTS AND INTERSTATE SPILLOVERS: } \\
\text { THE AUSTRALIAN EXPERIENCE }\end{array}$ \\
\hline 10.07 & Clements, K. & $\begin{array}{l}\text { REPORT OF THE } 2009 \text { PHD CONFERENCE IN } \\
\text { ECONOMICS AND BUSINESS }\end{array}$ \\
\hline 10.08 & Robertson, P.E. & $\begin{array}{l}\text { INVESTMENT LED GROWTH IN INDIA: HINDU } \\
\text { FACT OR MYTHOLOGY? }\end{array}$ \\
\hline 10.09 & Fu, D., Wu, Y. and Tang, Y. & $\begin{array}{l}\text { THE EFFECTS OF OWNERSHIP STRUCTURE AND } \\
\text { INDUSTRY CHARACTERISTICS ON EXPORT } \\
\text { PERFORMANCE }\end{array}$ \\
\hline 10.10 & Wu, Y. & $\begin{array}{l}\text { INNOVATION AND ECONOMIC GROWTH IN } \\
\text { CHINA }\end{array}$ \\
\hline 10.11 & Stephens, B.J. & $\begin{array}{l}\text { THE DETERMINANTS OF LABOUR FORCE } \\
\text { STATUS AMONG INDIGENOUS AUSTRALIANS }\end{array}$ \\
\hline 10.12 & Davies, M. & $\begin{array}{l}\text { FINANCING THE BURRA BURRA MINES, SOUTH } \\
\text { AUSTRALIA: LIQUIDITY PROBLEMS AND } \\
\text { RESOLUTIONS }\end{array}$ \\
\hline 10.13 & Tyers, R. and Zhang, Y. & APPRECIATING THE RENMINBI \\
\hline 10.14 & Clements, K.W., Lan, Y. and Seah, S.P. & $\begin{array}{l}\text { THE BIG MAC INDEX TWO DECADES ON } \\
\text { AN EVALUATION OF BURGERNOMICS }\end{array}$ \\
\hline 10.15 & Robertson, P.E. and Xu, J.Y. & $\begin{array}{l}\text { IN CHINA’S WAKE: } \\
\text { HAS ASIA GAINED FROM CHINA'S GROWTH? }\end{array}$ \\
\hline 10.16 & Clements, K.W. and Izan, H.Y. & $\begin{array}{l}\text { THE PAY PARITY MATRIX: A TOOL FOR } \\
\text { ANALYSING THE STRUCTURE OF PAY }\end{array}$ \\
\hline 10.17 & Gao, G. & WORLD FOOD DEMAND \\
\hline 10.18 & Wu, Y. & $\begin{array}{l}\text { INDIGENOUS INNOVATION IN CHINA: } \\
\text { IMPLICATIONS FOR SUSTAINABLE GROWTH }\end{array}$ \\
\hline 10.19 & Robertson, P.E. & DECIPHERING THE HINDU GROWTH EPIC \\
\hline 10.20 & Stevens, G. & $\begin{array}{l}\text { RESERVE BANK OF AUSTRALIA-THE ROLE OF } \\
\text { FINANCE }\end{array}$ \\
\hline 10.21 & Widmer, P.K., Zweifel, P. and Farsi, M. & $\begin{array}{l}\text { ACCOUNTING FOR HETEROGENEITY IN THE } \\
\text { MEASUREMENT OF HOSPITAL PERFORMANCE }\end{array}$ \\
\hline
\end{tabular}




\begin{tabular}{|l|l|l|}
\hline 10.22 & McLure, $\mathrm{M}$. & $\begin{array}{l}\text { ASSESSMENTS OF A. C. PIGOU'S FELLOWSHIP } \\
\text { THESES }\end{array}$ \\
\hline 10.23 & Poon, A.R. & $\begin{array}{l}\text { THE ECONOMICS OF NONLINEAR PRICING: } \\
\text { EVIDENCE FROM AIRFARES AND GROCERY } \\
\text { PRICES }\end{array}$ \\
\hline 10.24 & Halperin, D. & $\begin{array}{l}\text { FORECASTING METALS RETURNS: A BAYESIAN } \\
\text { DECISION THEORETIC APPROACH }\end{array}$ \\
\hline 10.25 & Clements, K.W. and Si. J. & $\begin{array}{l}\text { THE INVESTMENT PROJECT PIPELINE: COST } \\
\text { ESCALATION, LEAD-TIME, SUCCESS, FAILURE } \\
\text { AND SPEED }\end{array}$ \\
\hline 10.26 & Chen, A., Groenewold, N. and Hagger, A.J. & $\begin{array}{l}\text { THE REGIONAL ECONOMIC EFFECTS OF A } \\
\text { REDUCTION IN CARBON EMISSIONS }\end{array}$ \\
\hline 10.27 & $\begin{array}{l}\text { Siddique, A., Selvanathan, E.A. and } \\
\text { Selvanathan, S. }\end{array}$ & $\begin{array}{l}\text { REMITTANCES AND ECONOMIC GROWTH: } \\
\text { EMPIRICAL EVIDENCE FROM BANGLADESH, } \\
\text { INDIA AND SRI LANKA }\end{array}$ \\
\hline
\end{tabular}


ECONOMICS DISCUSSION PAPERS

2011

\begin{tabular}{|c|c|c|}
\hline $\begin{array}{l}\text { DP } \\
\text { NUMBER }\end{array}$ & AUTHORS & TITLE \\
\hline 11.01 & Robertson, P.E. & $\begin{array}{l}\text { DEEP IMPACT: CHINA AND THE WORLD } \\
\text { ECONOMY }\end{array}$ \\
\hline 11.02 & Kang, C. and Lee, S.H. & $\begin{array}{l}\text { BEING KNOWLEDGEABLE OR SOCIABLE? } \\
\text { DIFFERENCES IN RELATIVE IMPORTANCE OF } \\
\text { COGNITIVE AND NON-COGNITIVE SKILLS }\end{array}$ \\
\hline 11.03 & Turkington, D. & DIFFERENT CONCEPTS OF MATRIX CALCULUS \\
\hline 11.04 & Golley, J. and Tyers, R. & $\begin{array}{l}\text { CONTRASTING GIANTS: DEMOGRAPHIC CHANGE } \\
\text { AND ECONOMIC PERFORMANCE IN CHINA AND } \\
\text { INDIA }\end{array}$ \\
\hline 11.05 & Collins, J., Baer, B. and Weber, E.J. & $\begin{array}{l}\text { ECONOMIC GROWTH AND EVOLUTION: } \\
\text { PARENTAL PREFERENCE FOR QUALITY AND } \\
\text { QUANTITY OF OFFSPRING }\end{array}$ \\
\hline 11.06 & Turkington, D. & $\begin{array}{l}\text { ON THE DIFFERENTIATION OF THE LOG } \\
\text { LIKELIHOOD FUNCTION USING MATRIX } \\
\text { CALCULUS }\end{array}$ \\
\hline 11.07 & Groenewold, N. and Paterson, J.E.H. & $\begin{array}{l}\text { STOCK PRICES AND EXCHANGE RATES IN } \\
\text { AUSTRALIA: ARE COMMODITY PRICES THE } \\
\text { MISSING LINK? }\end{array}$ \\
\hline 11.08 & Chen, A. and Groenewold, N. & $\begin{array}{l}\text { REDUCING REGIONAL DISPARITIES IN CHINA: IS } \\
\text { INVESTMENT ALLOCATION POLICY EFFECTIVE? }\end{array}$ \\
\hline 11.09 & Williams, A., Birch, E. and Hancock, P. & $\begin{array}{l}\text { THE IMPACT OF ON-LINE LECTURE RECORDINGS } \\
\text { ON STUDENT PERFORMANCE }\end{array}$ \\
\hline 11.10 & Pawley, J. and Weber, E.J. & $\begin{array}{l}\text { INVESTMENT AND TECHNICAL PROGRESS IN THE } \\
\text { G7 COUNTRIES AND AUSTRALIA }\end{array}$ \\
\hline 11.11 & Tyers, R. & $\begin{array}{l}\text { AN ELEMENTAL MACROECONOMIC MODEL FOR } \\
\text { APPLIED ANALYSIS AT UNDERGRADUATE LEVEL }\end{array}$ \\
\hline 11.12 & Clements, K.W. and Gao, G. & QUALITY, QUANTITY, SPENDING AND PRICES \\
\hline 11.13 & Tyers, R. and Zhang, Y. & $\begin{array}{l}\text { JAPAN'S ECONOMIC RECOVERY: INSIGHTS FROM } \\
\text { MULTI-REGION DYNAMICS }\end{array}$ \\
\hline 11.14 & McLure, M. & A. C. PIGOU'S REJECTION OF PARETO’S LAW \\
\hline 11.15 & Kristoffersen, I. & $\begin{array}{l}\text { THE SUBJECTIVE WELLBEING SCALE: HOW } \\
\text { REASONABLE IS THE CARDINALITY } \\
\text { ASSUMPTION? }\end{array}$ \\
\hline 11.16 & Clements, K.W., Izan, H.Y. and Lan, Y. & VOLATILITY AND STOCK PRICE INDEXES \\
\hline 11.17 & Parkinson, $\mathrm{M}$. & $\begin{array}{l}\text { SHANN MEMORIAL LECTURE 2011: SUSTAINABLE } \\
\text { WELLBEING - AN ECONOMIC FUTURE FOR } \\
\text { AUSTRALIA }\end{array}$ \\
\hline 11.18 & Chen, A. and Groenewold, N. & $\begin{array}{l}\text { THE NATIONAL AND REGIONAL EFFECTS OF } \\
\text { FISCAL DECENTRALISATION IN CHINA }\end{array}$ \\
\hline 11.19 & Tyers, R. and Corbett, J. & $\begin{array}{l}\text { JAPAN'S ECONOMIC SLOWDOWN AND ITS } \\
\text { GLOBAL IMPLICATIONS: A REVIEW OF THE } \\
\text { ECONOMIC MODELLING }\end{array}$ \\
\hline 11.20 & Wu, Y. & $\begin{array}{l}\text { GAS MARKET INTEGRATION: GLOBAL TRENDS } \\
\text { AND IMPLICATIONS FOR THE EAS REGION }\end{array}$ \\
\hline
\end{tabular}




\begin{tabular}{|l|l|l|}
\hline 11.21 & Fu, D., Wu, Y. and Tang, Y. & $\begin{array}{l}\text { DOES INNOVATION MATTER FOR CHINESE HIGH- } \\
\text { TECH EXPORTS? A FIRM-LEVEL ANALYSIS }\end{array}$ \\
\hline 11.22 & Fu, D. and Wu, Y. & $\begin{array}{l}\text { EXPORT WAGE PREMIUM IN CHINA'S } \\
\text { MANUFACTURING SECTOR: A FIRM LEVEL } \\
\text { ANALYSIS }\end{array}$ \\
\hline 11.23 & Li, B. and Zhang, J. & $\begin{array}{l}\text { SUBSIDIES IN AN ECONOMY WITH ENDOGENOUS } \\
\text { CYCLES OVER NEOCLASSICAL INVESTMENT AND } \\
\text { NEO-SCHUMPETERIAN INNOVATION REGIMES }\end{array}$ \\
\hline 11.24 & Krey, B., Widmer, P.K. and Zweifel, P. & $\begin{array}{l}\text { EFFICIENT PROVISION OF ELECTRICITY FOR THE } \\
\text { UNITED STATES AND SWITZERLAND }\end{array}$ \\
\hline 11.25 & Wu, Y. & $\begin{array}{l}\text { ENERGY INTENSITY AND ITS DETERMINANTS IN } \\
\text { CHINA'S REGIONAL ECONOMIES }\end{array}$ \\
\hline & & \\
\hline
\end{tabular}


ECONOMICS DISCUSSION PAPERS

2012

\begin{tabular}{|l|l|l|}
\hline $\begin{array}{l}\text { DP } \\
\text { NUMBER }\end{array}$ & AUTHORS & TITLE \\
\hline 12.01 & Clements, K.W., Gao, G., and Simpson, T. & $\begin{array}{l}\text { DISPARITIES IN INCOMES AND PRICES } \\
\text { INTERNATIONALLY }\end{array}$ \\
\hline 12.02 & Tyers, R. & $\begin{array}{l}\text { THE RISE AND ROBUSTNESS OF ECONOMIC } \\
\text { FREEDOM IN CHINA }\end{array}$ \\
\hline 12.03 & Golley, J. and Tyers, R. & $\begin{array}{l}\text { DEMOGRAPHIC DIVIDENDS, DEPENDENCIES } \\
\text { AND ECONOMIC GROWTH IN CHINA AND INDIA }\end{array}$ \\
\hline 12.04 & Tyers, R. & LOOKING INWARD FOR GROWTH \\
\hline 12.05 & Knight, K. and McLure, M. & THE ELUSIVE ARTHUR PIGOU \\
\hline 12.06 & McLure, M. & $\begin{array}{l}\text { ONE HUNDRED YEARS FROM TODAY: A. C. } \\
\text { PIGOU'S WEALTH AND WELFARE }\end{array}$ \\
\hline 12.07 & Khuu, A. and Weber, E.J. & HOW AUSTRALIAN FARMERS DEAL WITH RISK \\
\hline & & \\
\hline & & \\
\hline & & \\
\hline & & \\
\hline
\end{tabular}

